\title{
Connexin Implication in the Control of the Murine Beta-Cell Mass
}

\author{
PHILIPPE KLEE, SMARAGDA LAMPRIANOU, ANNE CHAROLLAIS, DOROTHÉE CAILLE, ROSSELLA SARRO, \\ MANON CEDERROTH, JACQUES-ANTOINE HAEFLIGER, AND PAOLO MEDA
}

\begin{abstract}
Department of Pediatrics [P.K.], University Hospital of Geneva, Geneva 1211, Switzerland; Department of Cell Physiology and Metabolism [S.L., A.C., D.C., R.S., M.C., P.M.], University of Geneva, Medical School, Geneva 1206, Switzerland; Department of Medicine [J.-A.H.], University Hospital of Lausanne, Lausanne 1011, Switzerland
\end{abstract}

\begin{abstract}
Diabetes develops when the insulin needs of peripheral cells exceed the availability or action of the hormone. This situation results from the death of most beta-cells in type 1 diabetes, and from an inability of the beta-cell mass to adapt to increasing insulin needs in type 2 and gestational diabetes. We analyzed several lines of transgenic mice and showed that connexins (Cxs), the transmembrane proteins that form gap junctions, are implicated in the modulation of the beta-cell mass. Specifically, we found that the native $\mathrm{Cx} 36$ does not alter islet size or insulin content, whereas the Cx43 isoform increases both parameters, and Cx32 has a similar effect only when combined with GH. These findings open interesting perspectives for the in vitro and in vivo regulation of the beta-cell mass. (Pediatr Res 70: 142-147, 2011)
\end{abstract}

D iabetes results from insufficient secretion of insulin and/or abnormal sensitivity of peripheral cells to the hormone (1). Type 1 diabetes results from a massive autoimmune destruction of the insulin-producing pancreatic betacells (2). Type 2 diabetes results from a combination of increased insulin resistance of peripheral cells and failure of the beta-cell mass to adapt to the increased needs of insulin (3). Increased needs of insulin are also seen during pregnancy and result in gestational diabetes when beta-cells fail to adequately increase their secretion or mass. In view of the high prevalence of diabetes worldwide, and of the economic burden of current treatments, strategies aimed at increasing the betacell mass could represent a valuable alternative to current approaches. Increasing the beta-cell mass could help to overcome the peripheral resistance to insulin observed in type 2 and gestational diabetes and to improve the effect of cell replacement therapies. Indeed, islet transplantation can normalize blood glucose levels and may prevent the devastating complications of diabetes. However, beta-cells from cadaver pancreases are in such short supply that transplants can be provided only to a limited number of patients, especially because multiple donors are usually necessary to achieve insulin independence of one recipient. The in vitro expansion

Received September 23, 2010; accepted February 16, 2011.

Correspondence: Philippe Klee, M.D., Ph.D., Department of Pediatrics, University Hospital of Geneva, Rue Willy-Donzé 6, 1211 Geneva, Switzerland; e-mail: philippe.klee@hcuge.ch

Our work is supported by grants from the Swiss National Science Foundation (310000-122423, 310000-109402, CR32I3_129987), the Juvenile Diabetes Research Foundation (40-2011-11), and the European Union (FP-7, BETAIMAGE 222980; IMI, IMIDIA, C2008-T7). of isolated islets/islet cells could markedly improve this therapeutic option.

The beta-cell mass adapts to the changing needs of the body throughout life. Thus, the beta-cell population grows postnatally, at least until adolescence (4-6). Thereafter, the increase in beta-cell mass continues to an advanced age and is linearly correlated with body weight (7). However, when a critical threshold is reached, insulin secretion can no longer meet the needs of the body, leading to glucose intolerance or diabetes. Obesity and pregnancy increase the insulin needs and failure to sufficiently increase the beta-cell mass results in type 2 diabetes and gestational diabetes, respectively. Several factors are implicated in the regulation of the beta-cell mass in rodents (8), including glucose (9-11), insulin, IGF-I and -II (12-16), hepatocyte growth factor (HGF) (17), PTH-related protein (PTHrP) (18), GH, prolactin (PRL), placental lactogen (PL) (19), and glucagon-like peptide-1 (GLP-1) (20-22). However, the effect of each of these factors is quantitatively modest and may not necessarily occur in humans $(23,24)$. Analysis of the pregnancy situation indicates that other factors are influential in the regulation of beta-cell mass, including possibly the beta-to-beta cell communications that are mediated by connexins (Cxs) (24). These proteins, which form the gap junction domains of cell membranes (25-27), may be key in this process because they have been shown to affect cell proliferation and survival in different cell types (28). Cxs form a multigene family of 21 members in the human genome (27). $\mathrm{Cx} 36$ is the only $\mathrm{Cx}$ isoform expressed in pancreatic beta-cells (29). Here, we have investigated the effect of various $\mathrm{Cx}$ isoforms on the beta-cell mass and the size of pancreatic islets, using a series of existing (30-31) and newly created transgenic mice, which either overexpressed the native Cx36, were null for this protein, or expressed it in combination with other $\mathrm{Cx}$ isoforms, in the presence or absence of human $\mathrm{GH}(\mathrm{hGH})$.

\section{MATERIALS AND METHODS}

Animals. The KO-Cx36 mice were obtained from the Geneva colony, which was established with breeding pairs from the Willecke laboratory (32). All the RIP-Cx transgenic animals were generated in the Meda laboratory by microinjecting a $\mathrm{Cx} 36$, or a $\mathrm{Cx} 43$ transgene (Fig. 1) into zygotic pronuclei, as previously reported for $\mathrm{Cx} 32$ (30). The transgene was driven by the rat insulin promoter (RIP) for a specific expression in beta-cells. Genotype of littermates

Abbreviations: $\mathbf{C x}$, connexin; hGH, human GH; RIP, rat insulin promoter 

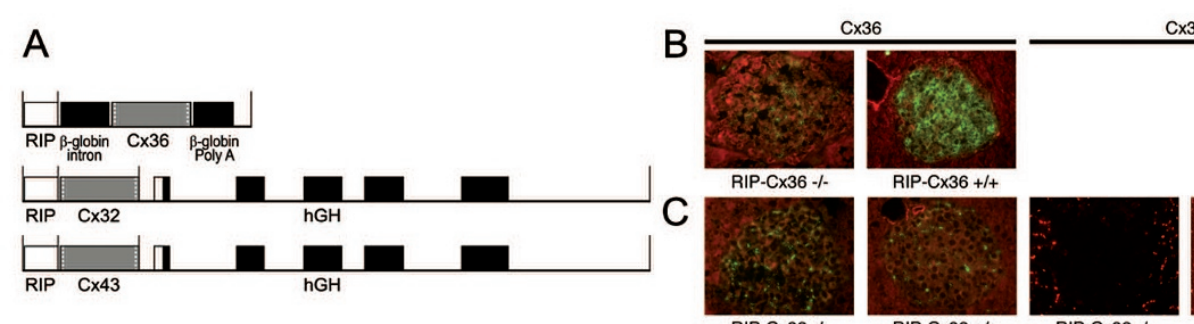

Cx32 Cx43
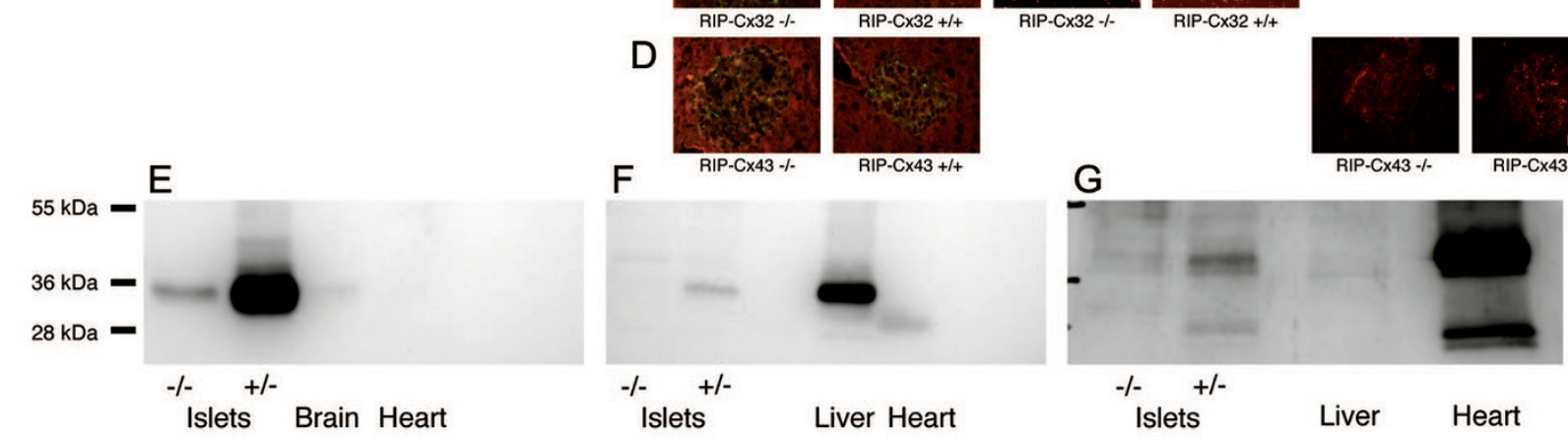

Figure 1. RIP-Cx32, -Cx36, and -Cx43 mice express a different Cx pattern in pancreatic islets. (A) RIP-Cx36 mice overexpress the native Cx36 specifically in beta-cells because they have a transgene driven by the RIP (top row). RIP-Cx32 and RIP-Cx43 mice express Cx 32 or Cx 43 on top of the native Cx36, because they have a corresponding transgene driven by the same RIP (middle and bottom row). (B) Immunolabeling of Cx36 on pancreatic sections of RIP-Cx36 mice shows overexpression of this protein in the beta-cells of these transgenic animals. (C) Immunolabeling of pancreatic sections of RIP-Cx32 mice shows control levels of $\mathrm{Cx} 36$ in control and transgenic animals. Cx32 was absent in control animals (RIP-Cx32-/-) and induced only in transgenic animals (RIP-Cx32 +/+). $(D)$ Immunolabeling of pancreatic sections of RIP-Cx43 mice shows control levels of Cx36 in control and transgenic animals. Cx43 was absent in control animals (RIP-Cx43-/-) and induced only in transgenic animals (RIP-Cx43 +/+). Bar, $120 \mu \mathrm{m}$. Islets from RIP-Cx36 (E), RIP-Cx32 (F), and RIP-Cx43 (G) mice were isolated, proteins were extracted and immunoblotted. Exposure of the membranes to an antibody directed against $\mathrm{Cx} 36(E), \mathrm{Cx} 32(F)$, or Cx43 $(G)$ revealed overexpression of Cx36 in transgenic RIP-Cx36 mice $(E)$, expression of Cx32 only in transgenic RIP-Cx32 mice $(F)$, and expression of Cx43 only in transgenic RIP-Cx43 mice $(G)$.

was determined by PCR amplification of tail DNA (30-33). Three- to six-mo-old mice backcrossed with C57B1/6 controls (F3-F5 generations) were used in all experiments, which were conducted as per the regulations of the veterinarian office of the State of Geneva (authorization No. 1034/3552/1, April 8, 2010).

Pancreas and islet sampling. Because circadian cycles may influence insulin expression, pancreases of all mice were consistently collected in the morning, for immunostaining, insulin extraction, and islet isolation. Islets of Langerhans were isolated for extraction of total proteins, as previously reported (29-31).

Measurement of insulin content. The pancreatic insulin was extracted and measured by RIA as previously reported (34). Values were normalized to the weight of the whole organ.

Measurement of islet surface. The size of pancreatic islets was measured on pancreatic sections immunostained for insulin, as previously reported (30) At least 100 islet sections were measured per animal, on pancreatic sections cut throughout the pancreas at intervals of $250 \mu \mathrm{m}$, in order not to measure the same islet twice (35). Three to four animals were evaluated for each genotype. Pictures were taken at a $400 \times$ magnification. Areas of islet profiles were measured using a graphic tablet and the Quantimet 500 software by Leica (Leica Microsystems, Heerbrugg, Switzerland) or digitized using a MIRAX MIDI slide scanner (Zeiss, Oberkochen, Germany) and analyzed using the MIRAX Viewer software.

Cx expression. The expression of $\mathrm{Cx} 32, \mathrm{Cx} 36$, and $\mathrm{Cx} 43$ within the islets of Langerhans was assessed by immunofluorescence staining of pancreas sections and by immunoblotting (Westerns) of total protein extracted from isolated islets, using specific antibodies, as reported in previous publications $(21-31,33)$.

Statistical analysis. Statistical analysis was performed using the Statistical Package for Social Sciences (SPSS 11.0.4, SPSS inc., Chicago). Briefly, the distribution of the data were analyzed by drawing a histogram of the values. For symmetrical distributions (insulin content), average data were expressed as mean \pm SEM. For asymmetrical distributions (islet size), average data were expressed as medians. Differences between means were assessed by $t$ test. Differences between medians were assessed by nonparametric tests for independent samples (median test, Mann-Whitney $U$, and KolmogorovSmirnov $Z$ tests). Differences were considered significant when $p<0.05$.

\section{RESULTS}

Animal characteristics. Cx expression of beta-cells was checked in the RIP-Cx transgenic mice by both immunofluorescence staining of pancreas sections and immunoblotting of total proteins extracted from isolated islets (Fig. 1). As expected, all control mice (-/- genotype) of the three RIP-Cx lines expressed limited levels of the native Cx36 but no detectable Cx32 or Cx43 (Fig. 1 and Table 1). The levels of Cx36 were significantly increased in the islets of RIP-Cx36 $+/+$ mice but not in those of either RIP-Cx32 $+/+$ or RIP-Cx43 $+/+$ animals (Fig. 1 and Table 1 ). Cx32 was only induced in the islets of RIP-Cx32 $+/+$ mice, whereas Cx43 was only induced in the islets of RIP-Cx43 $+/+$ animals (Fig. 1 and Table 1). We previously reported on the presence of $\mathrm{Cx} 36$ in the islets of WT and heterozygous KO-Cx36 mice and its loss in the islets of KO-Cx36 -/littermates $(31,33)$.

The KO-Cx36, RIP-Cx36, and RIP-Cx43 transgenic mice had normal levels of plasma insulin and glucose and a normal tolerance to a glucose test (Refs. 31,33 and data not shown). In contrast, the RIP-Cx32 mice had higher basal insulin levels and lower basal circulating glucose than controls and were intolerant to the sugar (30).

Loss of Cx36 does not affect beta-cell mass. KO-CX36 mice, which showed a partial ( $+/-$ animals) or complete loss of Cx36 (-/- null mice; Fig. 1 and Table 1; Refs.31,33) showed a median islet size and pancreatic insulin content 
Table 1. Summary of the characteristics of the transgenic mice used in this study

\begin{tabular}{lccccc}
\hline & & \multicolumn{4}{c}{ Beta-cell Cxs } \\
\cline { 3 - 5 } Mouse type & Genotype & Cx36 & Cx32 & Cx43 & hGH \\
\hline C57B16 & $+/+$ & ++ & - & - & - \\
Cx36 & $+/+$ & ++ & - & - & - \\
& $+/-$ & + & - & - & - \\
\multirow{5}{*}{ RIP-Cx36 } & $-/-$ & - & - & - & - \\
& $-/-$ & ++ & - & - & - \\
& $+/-$ & +++ & - & - & - \\
RIP-Cx43 & $+/+$ & ++++ & - & - & - \\
& $-/-$ & ++ & - & - & - \\
& $+/-$ & ++ & - & + & - \\
RIP-Cx32 & $+/+$ & ++ & - & ++ & - \\
& $-/-$ & ++ & - & - & - \\
& $+/-$ & ++ & + & - & + \\
RIP-hGH & $+/+$ & ++ & ++ & - & ++ \\
& $-/-$ & ++ & - & - & - \\
& $+/-$ & ++ & - & - & + \\
& $+/+$ & ++ & - & - & ++ \\
& +1 & + & + & +
\end{tabular}

Symbols in columns provide an evaluation of the relative levels of $\mathrm{Cx} 36$, $\mathrm{Cx} 32, \mathrm{Cx} 43$, and hGH in beta-cells, as determined by immunolabeling of sections and/or islet membranes. Bold symbols outline native levels of $\mathrm{Cx} 36$. - not detectable; + to ++++ increasing levels. All KO (Cx36) and transgenic lines (RIP-Cx36, RIP-Cx32, RIP-Cx43, RIP-hGH) were backcrossed with C57B16 mice. The mice that served as controls for the different lines (Cx36 +/+, RIP-Cx36 -/-, RIP-Cx43 -/-, RIP-Cx32 -/-, RIPhGH -/-) featured native levels of Cx36, like WT C57B16 controls.

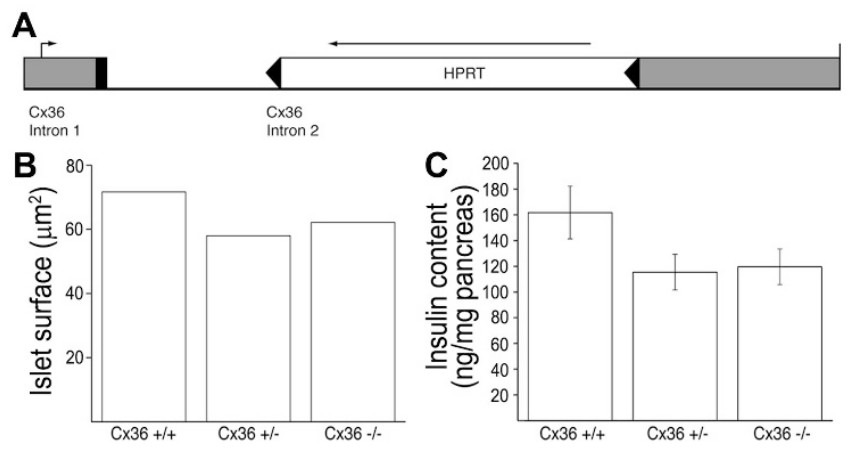

Figure 2. Loss of $\mathrm{Cx} 36$ does not affect beta-cell mass. (A) In the KO-Cx36 mice, the coding region of the $\mathrm{Cx} 36$ gene was replaced by a HPRT minigene transcribed in an antisense direction. Measurement of islet sections $(B)$ and of pancreatic insulin content $(C)$ showed that there was no significant difference in these parameters between transgenic mice and their control littermates. $(B)$ Values are medians of $1192(\mathrm{Cx} 36+/+), 1220(\mathrm{Cx} 36+/-)$, and 1590 islets (Cx36-/-). Differences between medians were assessed by the median, the Mann-Whitney $U$ and the Kolmogorov-Smirnov $Z$ tests. $(C)$ Values are means \pm SEM of $15(\mathrm{Cx} 36+/+), 17(\mathrm{Cx} 36+/-)$, and 16 pancreas $(\mathrm{Cx} 36$ $-/-)$. Differences between means were assessed by $t$ test.

similar to those evaluated in their control $(+/+)$ littermates (Fig. 2). Thus, loss of Cx36 levels did not alter beta-cell mass.

Overexpression of Cx36 does not affect beta-cell mass. RIP-Cx36 mice, which overexpressed Cx36 specifically in beta-cells (Fig. 1 and Table 1), showed an islet size and pancreas insulin content similar to those of their control littermates (Fig. 3). Thus, increased levels of Cx36 did not alter beta-cell mass.

The beta-cell-specific expression of ectopic Cxs increases the beta-cell mass. RIP-Cx32 mice featured significantly larger islets and a higher insulin content than their control
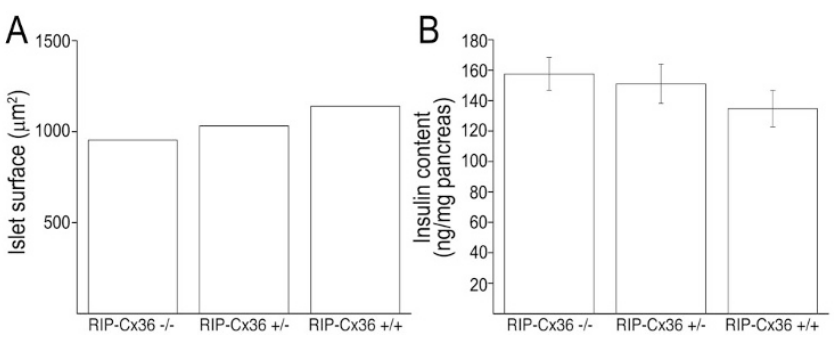

Figure 3. Overexpression of $\mathrm{Cx} 36$ does not affect beta-cell mass. RIP-Cx36 mice overexpress $\mathrm{Cx} 36$ specifically in beta-cells. These transgenic mice featured an islet size $(A)$ and total insulin content similar to those evaluated in control littermates $(B)$. (A) Values are medians of 532 (RIP-Cx36 -/-), 546 (RIP-Cx36 +/-), and 612 islets (RIP-Cx36 +/+). Differences between medians were assessed by the median, the Mann-Whitney $U$ and the Kolmogorov-Smirnov $Z$ tests. (B) Values are mean \pm SEM of 16 (RIP-Cx36-/-), 14 (RIP-Cx36+/-), and 10 pancreas (RIP-Cx36+/+). Differences between means were assessed by $t$ test.
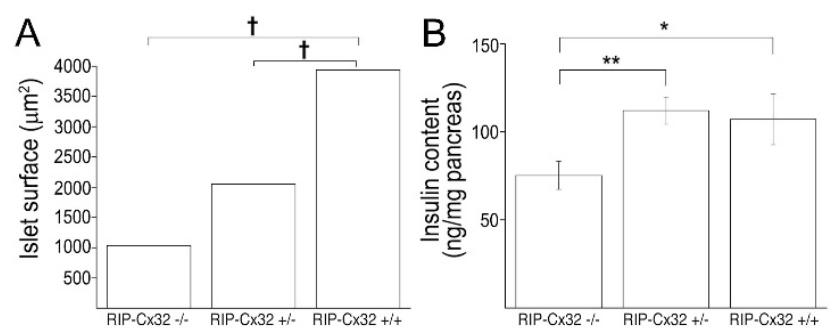

Figure 4. Co-expression of $\mathrm{Cx} 32$ and hGH, on top of $\mathrm{Cx} 36$, increases beta-cell mass. RIP-Cx32 mice express $\mathrm{Cx} 32$ and hGH, on top of the endogenous $\mathrm{Cx} 36$. These transgenic mice featured significantly larger islets (A) and insulin content $(B)$ than their littermate controls. (A) Values are medians of 1850 (RIP-Cx32-/-), 975 (RIP-Cx32 \pm ), and 1158 islets (RIP-Cx32+/+). Differences between medians were assessed by the median, the Mann-Whitney $U$ and the Kolmogorov-Smirnov $Z$ tests. $(B)$ Values are means \pm SEM of 11 (RIP-Cx32 - /- and RIP-Cx32+/-) and 6 pancreas (RIP-Cx32 +/+). *p $<0.05 ; * * p<0.01 ; \dagger p<0.001$. Differences between means were assessed by $t$ test.

littermates (Fig. 4). These mice expressed $\mathrm{Cx} 32$ and hGH on top of the native Cx36 (Table 1 and Figs. 1 and $5 G$ ) Thus, when expressed with hGH, Cx32 increases islet size and beta-cell mass.

To determine whether this effect was because of $\mathrm{Cx} 32$, $\mathrm{hGH}$, or to the combination of the two proteins, we similarly investigated RIP-hGH mice, which express high levels of hGH in beta-cells (Fig. $5 F$ and Table 1). These transgenic mice featured an average islet size increased 2-fold compared with controls (Fig. 6A). However, total pancreatic insulin content was similar in the transgenic mice and their control littermates (Fig. 6B). Thus, hGH increases islet size but not the total mass of beta-cells.

We similarly studied RIP-Cx43 mice in which beta-cells express $\mathrm{Cx} 43$ on top of the native $\mathrm{Cx} 36$ but no hGH (Table 1 and Figs. 1 and $5 E$ and $G$ ). We found that these transgenic mice had larger islets than controls (Fig. 7A). In the homozygous $(+/+)$, but not the heterozygous $(+/-)$ littermates, this change was paralleled by an increase in total insulin content (Fig. 7B). Thus, overexpression of $\mathrm{Cx} 43$ increases islet size and beta cell mass in the absence of hGH. 


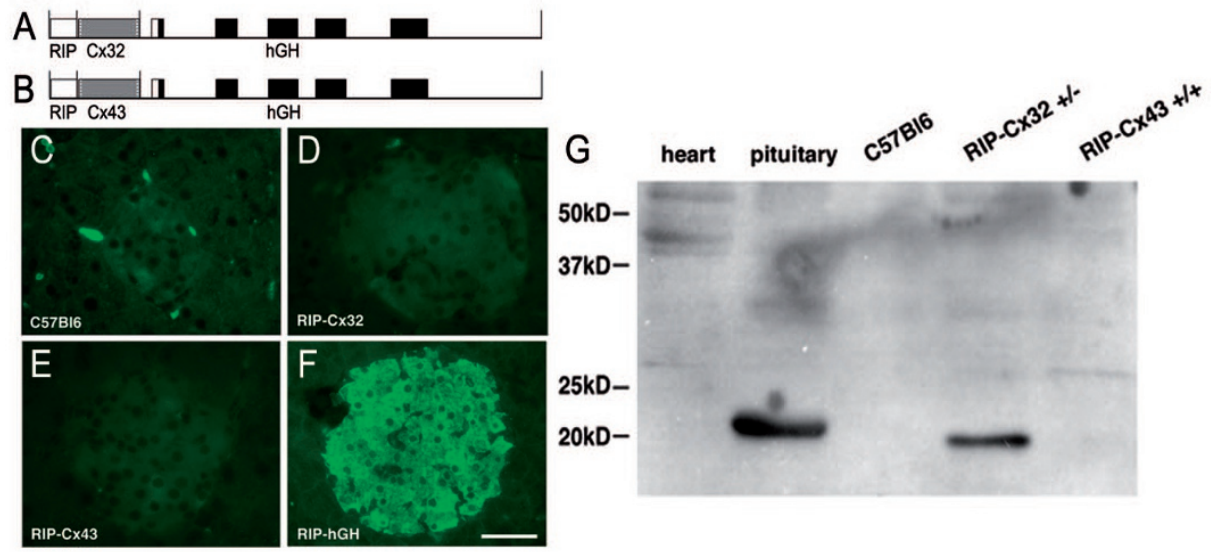

Figure 5. hGH is expressed in RIP-hGH and RIP-Cx32 but not in RIP-Cx43 mice. (A) In RIP-Cx32 mice, the expression of the Cx32 cDNA is regulated by the RIP. The complete sequence of the hGH follows the Cx32 cDNA to provide the transgene with introns and a polyadenylation sequence. $(B)$ In RIP-Cx43 mice, the expression of the Cx43 cDNA is similarly regulated by the RIP and followed by the complete sequence of hGH. $(C-F)$ Immunolabeling of hGH reveals that this hormone is expressed in RIP-hGH mice $(F)$ but is not detectable in either homozygous RIP-Cx32 $(D)$ or RIP-Cx43 mice $(E)$. Bar, $30 \mu \mathrm{m}$ in $C, D$, and $E$, and $60 \mu \mathrm{m}$ in $F$. $(G)$ Islets from RIP-Cx32 and RIP-Cx43 mice were isolated, proteins were extracted and immunoblotted. Exposure of the membrane to an antibody directed against hGH revealed expression of this hormone in heterozygous mice of the RIP-Cx32 mouse line but not in homozygous animals of the RIP-Cx43 mouse line. Proteins from heart and the pituitary gland were used as negative and positive controls, respectively.
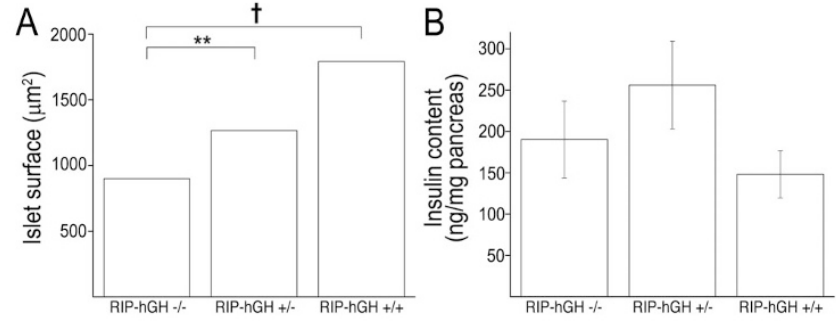

Figure 6. Expression of hGH increases islet size but not insulin content. In RIP-hGH mice, which express high levels of hGH in beta-cells, the average islet size was significantly increased compared with controls $(A)$. However, there was no significant difference in the total pancreatic insulin content between transgenic mice and their control littermates $(B)$. (A) Values are medians of 400 (RIP-hGH -/-), 612 (RIP-hGH +/-), and 606 islets $($ RIP-hGH $+/+$ ). Differences between medians were assessed by the median, the Mann-Whitney $U$, and the Kolmogorov-Smirnov $Z$ tests. $(B)$ Values are means \pm SEM of 7 (RIP-hGH $-/-$ ), 9 (RIP-hGH +/-), and 13 pancreas (RIP-hGH $+/+$ ). $* * p<0.01 ; \dagger p<0.001$. Differences between means were assessed by $t$ test.

\section{DISCUSSION}

By comparing mice expressing different $\mathrm{Cx}$ patterns, we have found that $\mathrm{Cx} 36$ has no effect on islet size and beta-cell mass, that $\mathrm{Cx} 32$ in association with hGH increases these two parameters, and that $\mathrm{Cx} 43$ has the same effect also in the absence of the latter hormone. The data indicate for the first time that some $\mathrm{Cx}$ species are implicated in the adaptation of pancreatic beta-cells. The finding is noteworthy, inasmuch as modest increases in beta-cell mass have now been documented, at least in rodents, under a variety of experimental conditions of partial pancreas and/or islet cell ablation $(8,24,36)$. However, no physiological condition has yet been shown to induce a sizable increase of beta-cell mass, with the notable exception of pregnancy $(23,24,37)$. Our findings indicate that Cxs may be central to the regulation of beta-cell life in nonpregnant, normoglycemic animals. Strikingly, significant changes in the direct communications that beta-cells
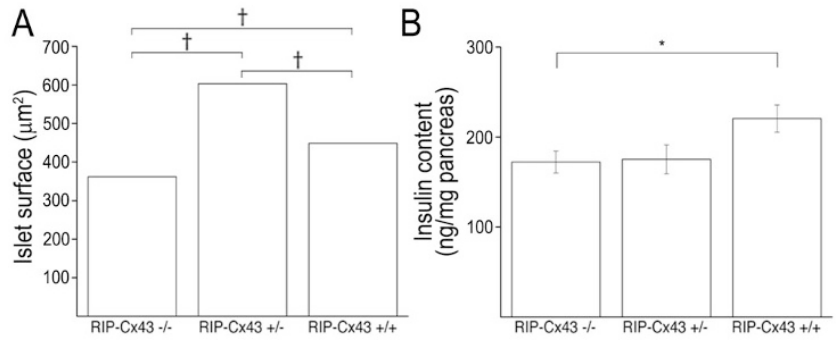

Figure 7. Expression of $\mathrm{Cx} 43$ on top of $\mathrm{Cx} 36$ increases the beta-cell mass. RIP-Cx43 mice express Cx43 on top of the endogenous Cx36. These transgenic mice featured significantly larger islets $(A)$, and insulin content $(B)$, reflecting an increased beta-cell mass. (A) Values are medians of 2245 (RIP-Cx43-/-), 2055 (RIP-Cx43 +/-), and 2216 islets (RIP-Cx43 +/+). Differences between medians were assessed by the median, the MannWhitney $U$, and the Kolmogorov-Smirnov $Z$ tests. $(B)$ Values are means \pm SEM of 18 (RIP-Cx43-/-), 19 (RIP-Cx43+/-), and 10 pancreas (RIP$\mathrm{Cx} 43+/+$ ) measurements. $* p<0.05 ; * * p<0.01 ; \dagger p<0.001$. Differences between means were assessed by $t$ test.

establish via $\mathrm{Cx}$ channels have also been reported in rodent pregnancy (37), even though the Cx species involved was not investigated (24).

In keeping with the different permeability and regulatory properties of the channels made by different $\mathrm{Cx}$ species $(28,35,38-40)$, we have found that specific Cxs also had differential effects on both islet size and the total insulin content of pancreas, which are two widely accepted indicators of beta-cell mass, in the various null and transgenic strains we compared. Thus, the native Cx36 seemed not to affect betacell mass in agreement with its restricted expression in only poorly proliferating pancreatic beta-cells, adrenal medulla cells, and most neurons (26). In contrast, the much more widespread $\mathrm{Cx} 32$ and $\mathrm{Cx} 43$ did so in the presence of native levels of Cx36. However, it is most unlikely that the beta-cell changes were because of the persistent expression of the latter $\mathrm{Cx}$, given that $\mathrm{Cx} 36$ does not form heterotypic channels with other Cx species $(28,38)$. 
Because to ectopically express Cxs in beta-cells, we used the hGH gene as a source of stabilizing polyadenylation sequences, and because $\mathrm{GH}$ has a potent in vitro mitogenic effect on beta-cells (41), we checked whether this hormone alone could account for the beta-cell changes we detected in RIP-Cx 32 and Cx43 mice. We found that the sole expression of hGH in beta-cells did not increase insulin content, even though it enlarged the size of individual pancreatic islets. We further observed that hGH was expressed in RIP-Cx32 but not RIP-Cx43 mice. Thus, in the former animal strain, the effects of Cx32 may have been synergized by those of hGH. This hormone is known to exert its effects via the JAK-STAT signaling pathway, generating transcription factors that control the expression of multiple target genes (19). However, this potential synergy cannot account for the changes we observed in the RIP-Cx43 mice, given that these animals did not express hGH. Thus, Cx43 had a remarkable effect on both islet size (in both heterozygous and homozygous mice) and insulin content (only in the latter animals). The underlying mechanism, which could involve increased beta-cell coupling, interactions between Cxs with either membrane or cytosolic proteins $(39,42)$, possibly resulting in altered expression of specific genes (39) involved in beta-cell differentiation and/or proliferation, remains to be investigated. Strikingly, the actively proliferating embryonic stem cells that may provide a source for the generation of secretory competent and nonproliferating insulin-producing cells useful in a cell replacement therapy of diabetes express Cx43 but no Cx36 (43-45).

The mass of the insulin-producing beta-cells is the balanced result of several factors including changes in beta-cell size, proliferation, life time and cell death, and possibly other mechanisms such as islet cell transdifferentiation and islet neogenesis $(8,24)$. The relative impact of each of these mechanisms may vary under different physiological and pathophysiological conditions $(8,24)$. The new animal models we report here offer unique tools to further investigate these events and the underlying molecular mechanisms. Parallel studies have revealed that the three $\mathrm{Cx}$ species we investigated protect beta-cells in vivo and in vitro against drugs and cytokines that induce beta-cell apoptosis and necrosis, preventing the resulting hyperglycemia (46). Whether the Cxs are also central to the regulation of beta-cell life in the normoglycemic animals that we have screened here remains to be determined and will be the subject of further studies. Under physiological conditions, beta-cell proliferation and apoptosis is an infrequent event, and islet neogenesis and islet transdifferentiation are still questioned phenomena $(8,24)$. Thus, such studies will require long periods of analysis of large numbers of animals.

At any rate, our findings open the possibility that an in vivo modulation of the beta-cell mass is possible by modifying the expression of specific Cxs. Cx36 could do so by reducing the constitutive beta-cell death and improving beta-cell function (26,46), Cx32 and Cx43 by increasing beta-cell formation, as indicated by this study. The sequential, regulated expression of these proteins is a novel and attractive strategy to improve the outcome of islet and beta-cell transplantation procedures, which are presently limited by significant losses of the transplanted islets before grafting $(47,48)$.

\section{REFERENCES}

1. Craig ME, Hattersley A, Donaghue KC 2009 Definition, epidemiology and classification of diabetes in children and adolescents. Pediatr Diabetes 10:3-12

2. Mathis D, Vence L, Benoist C 2001 Beta-cell death during progression to diabetes. Nature 414:792-798

3. Stumvoll M, Goldstein BJ, Haeften TW 2005 Type 2 diabetes: principles of pathogenesis and therapy. Lancet 365:1333-1346

4. Bouwens L, Wang RN, De Blay E, Pipeleers DG, Kloppel G 1994 Cytokeratins as markers of ductal cell differentiation and islet neogenesis in the neonatal rat pancreas. Diabetes 43:1279-1283

5. Dor Y, Brown J, Martinez OI, Melton DA 2004 Adult pancreatic beta-cells are formed by self-duplication rather than stem-cell differentiation. Nature 429:41-46

6. Finegood DT, Scaglia L, Bonner-Weir S 1995 Dynamics of beta-cell mass in the growing rat pancreas. Estimation with a simple mathematical model. Diabetes 44:249-256

7. Montanya E, Nacher V, Biarnes M, Soler J 2000 Linear correlation between beta-cell mass and body weight throughout the lifespan in Lewis rats: role of beta-cell hyperplasia and hypertrophy. Diabetes 49:1341-1346

8. Bouwens L, Rooman I 2005 Regulation of pancreatic beta-cell mass. Physiol Rev $85: 1255-1270$

9. Butler AE, Janson J, Bonner-Weir S, Ritzel R, Rizza RA, Butler PC 2003 Beta-cell deficit and increased beta-cell apoptosis in humans with type 2 diabetes. Diabetes 52:102-110

10. Donath MY, Gross DJ, Cerasi E, Kaiser N 1999 Hyperglycemia-induced beta-cell apoptosis in pancreatic islets of Psammomys obesus during development of diabetes. Diabetes 48:738-744

11. Swenne I 1982 The role of glucose in the in vitro regulation of cell cycle kinetics and proliferation of fetal pancreatic B-cells. Diabetes 31:754-760

12. Devedjian JC, George M, Casellas A, Pujol A, Visa J, Pelegrin M, Gros L, Bosch F 2000 Transgenic mice overexpressing insulin-like growth factor-II in beta cells develop type 2 diabetes. J Clin Invest 105:731-740

13. Hogg J, Han VK, Clemmons DR, Hill DJ 1993 Interactions of nutrients, insulin-like growth factors (IGFs) and IGF-binding proteins in the regulation of DNA synthesis by isolated fetal rat islets of Langerhans. J Endocrinol 138:401-412

14. Ohsugi M, Cras-Meneur C, Zhou Y, Bernal-Mizrachi E, Johnson JD, Luciani DS, Polonsky KS, Permutt MA 2005 Reduced expression of the insulin receptor in mouse insulinoma (MIN6) cells reveals multiple roles of insulin signaling in gene expression, proliferation, insulin content, and secretion. J Biol Chem 280:4992-5003

15. Sieradzki J, Fleck H, Chatterjee AK, Schatz H 1988 Stimulatory effect of insulin-like growth factor-I on $[3 \mathrm{H}]$ thymidine incorporation, DNA content and insulin biosynthesis and secretion of isolated pancreatic rat islets. J Endocrinol 117:59-62

16. Swenne I, Hill DJ, Strain AJ, Milner RD 1987 Growth hormone regulation of somatomedin C/insulin-like growth factor I production and DNA replication in fetal rat islets in tissue culture. Diabetes 36:288-294

17. Garcia-Ocaña A, Takane KK, Syed MA, Philbrick WM, Vasavada RC, Stewart AF 2000 Hepatocyte growth factor overexpression in the islet of transgenic mice increases beta cell proliferation, enhances islet mass, and induces mild hypoglycemia. J Biol Chem 275:1226-1232

18. Vasavada RC, Gonzalez-Pertusa JA, Fujinaka Y, Fiaschi-Taesch N, CozarCastellano I, Garcia-Ocana A 2006 Growth factors and beta cell replication. Int J Biochem Cell Biol 38:931-950

19. Nielsen JH, Svensson C, Galsgaard ED, Moldrup A, Billestrup N 1999 Beta cell proliferation and growth factors. J Mol Med 77:62-66

20. Drucker DJ 2003 Glucagon-like peptides: regulators of cell proliferation, differentiation, and apoptosis. Mol Endocrinol 17:161-171

21. Li Y, Cao X, Li LX, Brubaker PL, Edlund H, Drucker DJ 2005 beta-Cell Pdx1 expression is essential for the glucoregulatory, proliferative, and cytoprotective actions of glucagon-like peptide-1. Diabetes 54:482-491

22. Wang Q, Brubaker PL 2002 Glucagon-like peptide-1 treatment delays the onset of diabetes in 8 week-old db/db mice. Diabetologia 45:1263-1273

23. Butler AE, Cao-Minh L, Galasso R, Rizza RA, Corradin A, Cobelli C, Butler PC 2010 Adaptive changes in pancreatic beta cell fractional area and beta cell turnover in human pregnancy. Diabetologia 53:2167-2176

24. Genevay M, Pontes H, Meda P 2010 Beta cell adaptation in pregnancy: a major difference between humans and rodents. Diabetologia 53:2089-2092

25. Evans WH, De Vuyst E, Leybaert L 2006 The gap junction cellular internet: connexin hemichannels enter the signalling limelight. Biochem J 397:1-14

26. Michon L, Nlend Nlend R, Bavamian S, Bischoff L, Boucard N, Caille D, Cancela J, Charollais A, Charpantier E, Klee P, Peyrou M, Populaire C, Zulianello L, Meda P 2005 Involvement of gap junctional communication in secretion. Biochim Biophys Acta 1719:82-101

27. Söhl G, Willecke K 2004 Gap junctions and the connexin protein family. Cardiovasc Res 62:228-232

28. Harris AL, Locke D 2009 Connexins: A Guide. Springer, New York, pp 573

29. Serre-Beinier V, Le Gurun S, Belluardo N, Trovato-Salinaro A, Charollais A, Haefliger JA, Condorelli DF, Meda P 2000 Cx36 preferentially connects beta-cells within pancreatic islets. Diabetes 49:727-734

30. Charollais A, Gjinovci A, Huarte J, Bauquis J, Nadal A, Martin F, Andreu E, Sanchez-Andres JV, Calabrese A, Bosco D, Soria B, Wollheim CB, Herrera PL, Meda P 2000 Junctional communication of pancreatic beta-cells contributes to the control of insulin secretion and glucose tolerance. J Clin Invest 106:235-243

31. Ravier MA, Güldenagel M, Charollais A, Gjinovci A, Caille D, Söhl G, Wollheim CB, Willecke K, Henquin J-C, Meda P 2005 Loss of connexin36 channels alters beta-cell coupling, islet synchronization of glucose-induced $\mathrm{Ca} 2+$ and insulin oscillations, and basal insulin release. Diabetes 54:1798-1807 
32. Güldenagel M, Ammermüller J, Feigenspan A, Teubner B, Degen J, Söhl G, Willecke K, Weiler R 2001 Visual transmission deficits in mice with targeted disruption of the gap junction gene connexin36. J Neurosci 21:6036-6044

33. Wellershaus K, Degen J, Deuchars J, Theis M, Charollais A, Caille D, Gauthier B, Janssen-Bienhold U, Sonntag S, Herrera P, Meda P, Willecke K 2008 A new conditional mouse mutant reveals specific expression and functions of connexin 36 in neurons and pancreatic beta-cells. Exp Cell Res 314:997-1012

34. Meda P, Bosco D, Chanson M, Giordano E, Vallar L, Wollheim C, Orci L 1990 Rapid and reversible secretion changes during uncoupling of rat insulin-producing cells. J Clin Invest 86:759-768

35. Charpantier E, Cancela J, Meda P 2007 Beta cells preferentially exchange cationic molecules via connexin 36 gap junction channels. Diabetologia 50:2332-2341

36. Collombat P, Xu X, Heimberg H, Mansouri A 2010 Pancreatic beta-cells: from generation to regeneration. Semin Cell Dev Biol 21:838-844

37. Sorenson RL, Brelje TC 1997 Adapation of islets of Langerhans to pregnancy: beta-cell growth, enhanced insulin secretion and the role of lactogenic hormones. Horm Metab Res 29:301-307

38. Harris AL 2001 Emerging issues of connexin channels: biophysics fills the gap. Q Rev Biophys 34:325-472

39. Kardami E, Dang X, Iacobas DA, Nickel BE, Jeyaraman M, Srisakuldee W, Makazan J, Tanguy S, Spray DC 2007 The role of connexins in controlling cell growth and gene expression. Prog Biophys Mol Biol 94:245-264

40. Srinivas M, Rozental R, Kojima T, Dermietzel R, Mehler M, Condorelli DF, Kessler JA, Spray DC 1999 Functional properties of channels formed by the neuronal gap junction protein connexin36. J Neurosci 19:9848-9855
41. Nielsen JH, Galsgaard ED, Moldrup A, Friedrichsen BN, Billestrup N, Hansen JH, Lee YC, Carlsson C 2001 Regulation of beta-cell mass by hormones and growth factors. Diabetes 50:S25-S29

42. Li X, Olson C 2004 Association of connexin36 with zonula occludens-1 in HeLa cells, betaTC-3 cells, pancreas, and adrenal gland. Histochem Cell Biol 122:485498

43. Oyamada Y, Komatsu K, Kimura H, Mori M, Oyamada M 1996 Differential regulation of gap junction protein (connexin) genes during cardiomyocytic differentiation of mouse embryonic stem cells in vitro. Exp Cell Res 229:318-326

44. Todorova MG, Soria B, Quesada I 2008 Gap junctional intercellular communication is required to maintain embryonic stem cells in a non-differentiated and proliferative state. J Cell Physiol 214:354-362

45. Wörsdörfer P, Maxeiner S, Markopoulos C, Kirfel G, Wulf V, Auth T, Urschel S, Von Maltzahn J, Willecke K 2008 Connexin expression and functional analysis of gap junctional communication in mouse embryonic stem cells. Stem Cells 26:431439

46. Klee P, Bavamian S, Charollais A, Caille D, Cancela J, Peyrou M, Meda P 2008 Gap junctions and insulin secretion. In: Seino S, Bell GI (eds) Pancreatic Beta Cell in Health and Disease. Springer, Tokyo, pp 111-132

47. Bottino R, Balamurugan AN 2002 Preservation of human islet cell functional mass by anti-oxidative action of a novel SOD mimic compound. Diabetes 51:2561-2567

48. Kin T, Senior P, O'Gorman D, Richer B, Salam A, Shapiro AM 2008 Risk factors for islet loss during culture prior transplantation. Transpl Int 21:1029-1035 